\title{
SMALL AND MEDIUM INDUSTRY FOR SUSTAINING MADRASA IN GLOBAL CHANGE (Study at Darul Ma'rifat Modern Islamic Boarding School in East Java)
}

\author{
Prima Aswirna \\ Writer is a Lecturer and Head Dept. of Science Education in Faculty of Education at State Institute of Islamic Studies \\ Imam Bonjol Padang \\ e-mail: primaaswirna1971@yahoo.com
}

\begin{abstract}
Any types and size of industry is required for the sustainable development of a Boarding School (Madrasa). Current study at Darul Ma'rifat Modern Islamic Boarding School in East Java is directed to describe: (1) the size and function of industry at Darul Ma'rifat Modern Islamic Boarding School; (2) the life-skill and the enterprenourships capability of the students; and (3) the effect of life-skills and the enterprenourships capability towards self-fulfilment attitude of students. All of the sixth grade students population (542 pupils) were randomly taken to get 226 students sample by using Slovin formula : $\mathrm{n}=\mathrm{N} / 1+\mathrm{N}$. $\mathrm{e}^{2}$. ( $\mathrm{n}=$ sample size, $1=$ constanta variable, $\mathrm{N}=$ population, $\mathrm{e}=$ standard error / 0,05). Data were collected through observation, psychological scale and interview. They were then analyzed using regression supported by Statistical Package of Social Science programme. The results show that: (1) There were thirty unit small and medium industry at Darul Ma'rifat Modern Islamic Boarding School. (2) Life-skills and the enterprenourships capability of the students were taught through practice like; working in bread industry and mini market etc. (3) The mean scored of lifeskills and the enterprenourships of the students were $82 \%$ categorized high.
\end{abstract}

Keywords : small and medium industry, life-skills, entreprenuerships capability and self-fulfilment.

\begin{abstract}
Abstrak: Jenis dan ukuran sebuah industry perlu bagi keberlanjutan pengembangan Pondok Pesantren. Penelitian yang dilakukan di PONPES Darul Ma'rifat, Jawa Timur ini bertujuan untuk mendeskripsikan: (1) Ukuran dan fungsi industri kecil dan menengah yang berada di pondok pesantren; (2) Keterampilan hidup dan kemampuan kewirausahaan yang dimiliki oleh para santri Pondok Pesantren Moderen Darul Ma'rifat; dan (3) Pengaruh keterampilan hidup dan kemampuan kewirausahaan terhadap sikap kemandirian pada para santri di Pondok Pesantren Moderen Darul Ma'rifat. Populasi dalam penelitian ini sebanyak 542 orang santri, mereka adalah santri kelas enam di Pondok Pesantren tersebut. Besaran ukuran sampel didasarkan pada penggunaan rumus Slovin : $\mathrm{n}=\mathrm{N} / 1+\mathrm{N} \cdot \mathrm{e}^{2}$. $(\mathrm{n}=$ ukuran sampel, $\mathrm{N}=$ populasi, $\mathrm{e}=$ standar kesalahan / 0,05). Hanya 226 orang santri dilibatkan dalam penelitian ini. Pemilihan sampel dilakukan secara acak (random). Teknik pengumpulan data dilakukan melalui observasi, skala psikologi dan wawancara. Data dianalisa dengan menggunakan metode statistik regresi. Hasil penelitian ini menunjukkan bahwa : (1) Terdapat tiga puluh industri kecil dan menengah yang dikembangkan pada Pondok Pesantren Moderen Darul Ma'rifat. (2) Keterampilan hidup dan kemampuan berwirausaha diajarkan melalui kegiatan praktik langsung di Pondok Pesantren Moderen Darul Ma'rifat. Seperi ; bekerja di pabrik roti dan mini market. (3) Skor rata-rata penyebaran keterampilan hidup dan kemampuan berwirausaha para santri tergolong tinggi, yakni sebanyak $82 \%$.
\end{abstract}

Kata Kunci : Industri kecil dan menengah, keterampilan hidup, kemampuan berwirausaha, sikap kemandirian.

\section{INTRODUCTION}

The Arabic word madrasa (plural: madaris) generally has two meanings: (1) in its more common literal and colloquial usage, it simply means "school"; (2) in its secondary meaning, a madrasa is an educational institution offering instruction in Islamic subjects including, but not limited to, the Quran, the sayings (hadith) of the Prophet Muhammad, jurisprudence (fiqh), and law. Historically, madrasas were distinguished as institutions of higher studies and existed in contrast to more rudimentary schools called kuttab that taughtt only the Quran. Recently, "madrasa" has been used as a catchall by many Western observers to denote any school - primary, secondary, or advanced - that promotes an Islamic-based curriculum. In many countries, including Egypt and Lebanon, madrasa refers to any educational institution (state-sponsored, private, secular, or religious). In Pakistan and Bangladesh, madrasa commonly refers to Islamic religious schools. 
This can be a significant semantic marker, because an analysis of "madrasa reform" could have different implications within various cultural, political, and geographic contexts. Unless otherwise noted in this paper, the term madrasa refers to Islamic religious schools at the primary and secondary levels.

As an institution of learning, the madrasa is centuries old. One of the first established madrasas, called the Nizamiyah, was built in Baghdad during the eleventh century A.D. Offering food, lodging, and a free education, madrasas spread rapidly throughout the Muslim world, and although their curricula varied from place to place, it was always religious in character because these schools ultimately were intended to prepare future Islamic religious scholars (ulama) for their work. In emphasizing classical traditions in Arabic linguistics, teachers lectured and students learned through rote memorization. During the nineteenth and early twentieth centuries, in the era of Western colonial rule, secular institutions came to supersede religious schools in importance throughout the Islamic world. However, madrasas were revitalized in the 1970s with the rising interest in religious studies and Islamist politics in countries such as Iran and Pakistan. In the 1980s, madrasas in Afghanistan and Pakistan were allegedly boosted by an increase in financial support from the United States, European governments, Saudi Arabia, and other Persian Gulf states all of whom reportedly viewed these schools as recruiting grounds for anti-Soviet mujahedin fighters. In the early 1990s, the Taliban movement was formed by Afghan Islamic clerics and students (talib means "student" in Arabic), many of whom were former mujahedin who had studied and trained in madrasas and who advocated a strict form of Islam similar to the Wahhabism practiced in Saudi Arabia and other Gulf countries.

Madrasas, in most Muslim countries today (included Indonesia), exist as part of a broader educational infrastructure. The private educational sector provides what is considered to be a quality Western-style education for those students who can afford high tuition costs. Because of their relatively lower costs, many people turn to state schools, where they exist. However, in recent years and in more impoverished nations, the rising costs and shortages of public educational institutions have encouraged parents to send their children to madrasas. Supporters of a state educational system have argued that the improvement of existing schools or the building of new ones could offer a viable alternative to religiousbased madrasas. Others maintain that reforms should be institutionalized primarily within Islamic madrasas in order to ensure a wellrounded curriculum at these popular institutions. In the U.S. Agency for International Development's (USAID) 2003 strategy paper Strengthening Education in the Muslim World, both of these viewpoints are advocated Although some madrasas teach secular subjects, in general madrasas offer a religious-based curriculum, focusing on the Quran and Islamic texts. Other concerns surround more moderate which students may be instructed to reject "immoral" and "materialistic" Western culture. The static curricula and dated pedagogical techniques, such as rote memorization, used in many quietist schools may also produce individuals who are neither skilled nor prepared for the modern workforce. Defenders of the madrasa system view its traditional pedagogical approach as a way to preserve an authentic Islamic heritage. Because most madrasa graduates have access to only to a limited type of education, they commonly are employed in the religious sector as prayer leaders and Islamic scholars. Authorities in various countries are considering proposals for introducing improved science and math content into madrasas curricula, while preserving the religious character of madrasa education.

As far as the history of Islamic education in Indonesia is concerned, modern pesantren (madrasa / madrasah) can be regarded as new genre of pesantren. The Pesantren Darussalam of Gontor, Ponorogo, was established in 20 September 1926 by three brothers - KH. Ahmad Sahal, KH. Zainuddin Fannani, and KH. Imam Zarkasyi. This madrasa is also called pondok modern (modern madrasa), in a sense that it not only adopts madrasah system, but also teaches Arabic and English to the students 
intensively and practically. In daily conversation among the students within the pesantren, all santris are obliged to speak Arabic or English - they are not allowed to speak Indonesian. In addition, unlike the majority of other madrasas, Modern Islamic Boarding School (I.e. Darul Ma'rifat, Gontor 3) includes the works of reformist Muslim thinkers in its curriculum. The works of Abduh, for instance, are placed as important subject matters in the pesantren. The objective of Pesantren Gontor, as mentioned by Lance Castle, is to produce kader Muslim (Muslim cadres) by combining the excellences of both traditional and modern pesantren education systems. In addition to secular subjects, the pesantren also urges the santris about the significance of art. Accordingly, music, sport and other extracurricular activities are among the concerns of pesantren's leaders. The pesantren is also intended to provide education capable of responding to Muslim challenges amid the socio-cultural life of Indonesian society which begin to enter modern world.

It is important to mention that Pesantren Gontor was established in the crucial period of Islamic development in Indonesia. Following the ethical politics implemented by the Dutch colonial administration, coupled with the establishment of international network with the center of Islamic reform in Cairo, Egypt, the Islamic education in Indonesia went through fundamental changes. This was marked by the establishment of new Islamic educational institutions, which adopt modern education system, instead of traditional education system of pesantren. The modern Islamic education institution - well-known as madrasa - then became an important part of Islamic reform movement during the early decades of 20th century.

Accordingly, in addition to introduce new system and instructional methods ranging from adopting grading model with class division, employing text books as learning tools, to accommodating secular subjects in the curriculum - madrasah functioned also as a media for the dissemination of Islamic reform ideas. It became the basis to prepare new Muslim generations who are familiar with the spirit of modernism, an issue that at that time was an overwhelming discourse in Indonesia which started to enter modern world. Accordingly, kader Muslims to be produced by Madrasa Gontor are those who are frequently identified as "Muslim intellectuals". The selfdefinition of Pesantren Gontor as a modern madrasa, as has been mentioned, is basically aimed at attempting itself to be in contrast to traditional madrasa, which is to some extent identical to stagnancy of thought, and to ineffective as well as inefficient managerial system of education. Imam Zarkasyi, one of the founding fathers of Madrasa Gontor, is of the opinion that a modern pesantren should implement freedom of thought, effective and efficient management, and introduce santri toward modernity. Parallel to other reformist Muslim, he also invites Muslims not to be too fanatical towards a certain madhhab, since this would lead to the absence of the freedom of thought. Indeed, with regard to religious ritual practices, Pesantren Gontor is not fanatical to a certain madhhab.

As far as the relation of pesantren and modernism is concerned, the effective and efficient management are described that pesantren should adopt a good, accountable and transparent administration and accounting system. Moreover, the managerial system of modern pesantren relates to the leadership system of pesantren. In this regards, Pesantren Gontor from its inception came up with an idea of what is termed as badan wakaf, the highest body within pesantren in which discussion and decision making are conducted. Under the badan wakaf is badan pelaksana (organizing body) which is responsible of the daily affairs of the pesantren. On the other hand, the introduction of santris toward modernity is implemented by providing them with Arabic and English language skills, Boy Scout, skills, and sports - activities unusual for traditional pesantrens. The manifestation of modern education of Pesantren Gontor can be seen from KMI (Kulliyatul Muallimin al-Islamiyah) system, i.e. a six-year secondary level of education (equal to SMP and SMU). In this respect, KMI constitutes a combination between madrasa and pesantren system. The decision to 
adopt this kind of education system was influenced by the school experiences of Imam Zarkasyi, from a pesantren in Solo, Thawalib of Padang Panjang in Sumatra, and Normal Islam School or also called Kulliyatul Muallimin alIslamiyah. In addition, it is also important to note here his experience in establishing and being the director of Muhammadiyah Kweekschool in Padang Sidempuan. With all those experiences, Imam Zarkasyi then tried to combine madrasa and modern school.

The main problems of this research : Explaining the effect of life-skills and entreprenourships capability and self-fulfilment attitude of students at Darul Ma'rifat Moderen Islamic Boarding School?. The aim of the research : (1) Describe about small and medium industry at Darul Ma'rifat Modern Islamic Boarding School. (2) Describe about the lifeskills and entreprenourships capability of students at Darul Ma'rifat Modern Islamic Boarding School. (3) Describe about an effect of life-skills and entreprenourships towards self-fulfilment attitude of students at Darul Ma'rifat Modern Islamic Boarding School.

\section{THEORITICAL BACKGROUND}

\section{(1) Empowering Madrasa}

The development of Islam in Indonesia is inseparable from its Islamic education system, especially pesantren and madrasah. Both institutions have played pivotal role in determining the religiosity of Indonesian society. Not only do they function as the center for Islamic learning, but also constitute inherent part in the formation of socio-cultural and religious system of Indonesian Muslims. As far as the Indonesian Muslim intellectual discourse is concerned, both institutions have played significant role as centers for the publication of Islamic scholarly works in Indonesia. Madrasa - with its other different names like pondok, dayah and meunasah — constitutes a model of traditional Islamic educational institution. An alim, or kyai, is the owner as well as the great teacher of pesantren. Most of the santri (students), both males and females, live in dormitory. Moreover, traditional Islamic knowledge, such as tafsir, hadith, fiqh, and tas \}awuf, are the main courses in pesantren. In addition, the learning process is conducted through traditional methods, without adopting grading and certification systems. Unlike pesantren, madrasah in Indonesian context is a modern educational institution. The emergence of madrasah by the end of 19th century was a critique towards pesantren education system. As a critique, madrasah tried to offer a wider range of curriculum design, including Islamic and secular courses, besides adopting grading and certification systems.

The recent development of Islamic education in Indonesia has shown that the modern madrasah expands itself into pesantren. From the outset, the reformists Muslims have addressed their critique towards pesantren. Mahmud Yunus, for instance, a leading figure of Islamic education reform of the beginning of the 21 st century criticized pesantren strongly by stating that "education system of traditional pesantren would only be able to produce one single ulama out of one hundred santris. The remaining 99 santris are merely contributors to purchase oil to prepare meals." Apart from the critiques addressed by reformist Muslims, the pesantren community themselves have actually begun to realize the significance of education system reform in pesantren. By the end of 19th century, pesantren community began to develop modern education system by adopting madrasah (school) system. With this new system, learning process in madrasa is conducted through grading, curriculum, and examination systems. Moreover, it also adopted modern learning methodology. Meanwhile, texts of classical Islam in various fields of knowledge such as 'ilm tafsir, 'ilm $\mathrm{h}$ \}adith, fiqh, usul al-fiqh, etc., remain studied in madrasa. Madrasa Tebuireng, Jombang, an old madrasa established in 1899 to name an example - is among the earlier madrasas which adopted madrasah education system. In its later development, Tebuireng also organized secular schools. Unsurprisingly thus, in Tebuireng we can find MTs and MA together with SMP and SMA. The education model developed by madrasa Tebuireng is now adopted by other madrasas. The expansion of modern madrasah system into madrasa continues to take place up to the present time. 
To some extent, madrasah has more advantages than secular school. First, madrasah possesses a strong root in community. This is because madrasahs are mostly established by community without any intervention of the government. People are donating their money voluntarily to support the necessities of madrasah. Second, given the voluntarily donation, financial issues in madrasah are relatively flexible in a sense that all the expenses of madrasah would depend on the real condition of the community earnings. Accordingly, a number of madrasahs in poor regions require a relatively cheap tuition fee for the students, while in few others it is more expensive. Madrasah teachers are generally doing their jobs due to religious reasons as their dedication and devotion. Teachers in a number of madrasahs of remote villages sometimes are paid with minimum salary, yet they are committed to their profession. Unsurprisingly, despite the economic crisis in Indonesia, madrasah not only continues to exist, but also becomes an alternative education for a few groups of community. Third, due to the affordable tuition fee of madrasah, it is regarded as education institution which takes side with poor people. Fourth, in terms of the participation of female students, madrasah constitutes education institution supportive to gender equity. Fifth, madrasah is an educational institution which offers pious norms to the pupils. Madrasah students are generally not getting involved in a number of delinquency attitudes, such as fighting amongst students of different schools. Sixth, Indonesian madrasah is unique compared to similar educational institution in other Muslim countries, since the former gives a balanced portion between Islamic and secular knowledge

The recent development of Indonesian Islam indicates that Islamic educational institutions survive amidst changes within Muslim communities. Madrasa, the oldest Islamic educational institution, is evidence of this. Madrasa, madrasah, and Islamic schools continue to grow and parental interest in sending their children to Islamic education institution is even stronger today than in the past. Data from the Department of Religious Affairs shows a steady increase in the number of madrasa and students enrolled in them. In 1977, there were 4,195 madrasa with 677,384 students. This number skyrocketed in 1981 with madrasa numbering 5,661 with a total of 938,397 students. In 1985, this number increased to 6,239 madrasa with $1,084,801$ students. In 1997, the Department reported 9,388 madrasa a total of 1,770,768 students. And finally, 2003-04, the number of madrasa reached 14,647. A similar trend is also evident with madrasa. Madrasa, managed by the Department of Religious Affairs, also experienced rapid quality and quantity development. Development trends are also evident in Islamic schools. For example, Al-Azhar School in Jakarta, Insan Cendikia and Madania in West Java, and Mutahhari in Bandung have grown significantly in urban regions of the country. Similar developments are also found in Yogyakarta, Surabaya, and Makassar.

These data raise some important questions concerning the development and survival of Islamic educational institutions, as well as their changing roles amid transitions taking place in the Muslim community. Islamic educational institutions face complex challenges. They not only strive to educate Muslims in religious knowledge, but are also expected to participate in creating a new socio-cultural and political system of Indonesia. Based on the characteristics of Islamic educational institutions, there are at least four types of Islamic educational institutions: (1) NU-based Islamic boarding schools, (2) modern Islamic boarding schools whose orientation are Islamic reformism, (3) independent madrasas, and (4) Islamic schools.

The Madrasa or Islamic boarding schools in Indonesia. According to one popular tradition, the madrasa education system originated from traditional Javanese pondokan; dormitories; ashram for Hindu or viharas for Buddhists to learn religious philosophies, martial arts and meditation. Institutions much like them are found across the Islamic world and are called pondok in Malaysia and Southern Thailand and madrasa Islamia (Islamic madrasa) in India and Pakistan and much of the Arabic speaking world. Madrasa aim to deepen knowledge of the Koran, particularly through 
the study of Arabic, traditions of exegesis, the Sayings of the Prophet, law and logic. The term madrasa derives from the root word santri or student -- pe-santri-an or the place of the santri. As social institutions, madrasa have played a major role over the centuries. They emphasise cores values of sincerity, simplicity, individual autonomy, solidarity and self-control. Young men and women are separated from their families, which contributes to a sense of individual commitment to the faith and close bonding to a teacher. Most 'madrasa' provide housing or dormitory living at low or no cost for the students (Santri). The two type of educations systems are conducted throughout the day. Students in madrasa have almost 20 hours activities starting from early morning prayer starting at $3 \mathrm{am}$ to midnight where they ended the evening with a study group in the dormitory. During the day, students attend formal school (which is mandatory until secondary school by 2005) like any other students outside of madrasa, and in late afternoon and evening they have to attend religious ritual followed by religious studies and group studies to complete their homework.

Madrasa provide to Indonesian citizens at low cost; although today some modern madrasa charge higher fees than previously, they are still significantly cheaper than nonmadrasa educational institutions. The traditional pattern was for students to work in the headmaster's rice fields in exchange for food, shelter, and education. All madrasa are led by a group of teachers and religious leaders known as Kyai. The Kyai is respected as teacher and devout man. Kyai also play important roles in the community as a religious leader and in recent years as a political figure. There are Kyai families that have a long history of serving in this role. Some contemporary Kyai are the grandsons and great-grandsons of famous historical figures who established well known madrasa. Starting in the second half of the Twentieth Century, some madrasa started adding secular subjects to their curriculum as a way of negotiating Modernity. The addition of state recognized curricula has affected traditional madrasa in a number of ways. It has led to greater control by the national government. It has also restricted the number of hours available for the traditional subjects making for difficult decisions. Many madrasa leaders have decided that the training of religious leaders is not their sole purpose and are now satisfied to graduate young men and women who have the morality of Kyai. The reduction of hours available to now master two curricula has led to practical changes. While it is still possible for the children of the poor to work in the Kyai's economic ventures (more than just rice fields these days), most parents will pay both room and board and small tuition. The time that used to be spent working, is now spent in secular education. Madrasa curriculum has four possible components: traditional religious education, called ngaji; government recognized curricula (there are two different types to choose from); vocational skills training; character development. In Gontor at least 31 other business units are managed by the school such as a printing shop, mini-market, bookshop, building materials store, bakery, drinking water factory, cattle breeding unit, and so on. The proceeds earned are spent on the daily needs of the school such as for the purchase of books and other teaching facilities, the construction of new buildings, etc. However, Gontor's educational and business activities are managed only by the school's clerics and students. The principle of self-reliance in funding all the activities of the school is just like that developed at Al-Azhar University in Egypt. That was developed from a mosque set up by the Egyptian ruler of Daulah Fatimiyyah. Self-reliance is also practiced at Syanggit Islamic Boarding School in Mauritania where the students are taughtt to manage businesses, such that the school has now developed into a large educational institution.

Currently, many other Islamic boarding schools in East Java have been developing the system adopted at Gontor as they believe their students must learn as many things as possible during their studies. Take, foreign language teaching, for example. Today not only Arabic is taughtt. About 60 percent of some 5,200 Islamic boarding schools in East Java include English in their curriculum. Some Islamic boarding schools, such as Lirboyo in Kediri, Genggong in 
Probolinggo and Manba'us Sholihin Suci in Gresik, even teach their students Chinese and German. One thing to be kept in mind in discussing Madrasa Gontor has their contribution in establishing new foundation for the development of madrasa in Indonesia.

(2) Small and Medium Industry

Small and medium enterprises (industry) or small and medium-sized enterprises (SMEs, small and medium-sized businesses, SMBs, and variations of these terms) are companies whose personnel numbers fall below certain limits. The abbreviation "SME" is used in the European Union and by international organizations such as the World Bank, the United Nations and the World Trade Organization (WTO). Small enterprises outnumber large companies by a wide margin and also employ many more people. SMEs are also said to be responsible for driving innovation and competition in many economic sectors. In July 2011, the European Commission said it would open a consultation on the definition of SMEs in 2012. In Europe, there are three broad parameters which define SMEs: (1) micro-entities are companies with up to 10 employees, (2) Small companies employ up to 50 workers, (3) Medium-sized enterprises have up to 250 employees.

According to German economist HansHeinrich Bass, "empirical research on SME as well as policies to promote SME have a long tradition in (West-)Germany, dating back into the 19th century. Until the mid-20th century most researchers considered SME as an impediment to further economic development and SME policies were thus designed in the framework of social policies. Only the ordoliberal school, the founding fathers of Germany's social market economy, discovered their strengths, considered SME as a solution to mid-20th century economic problems (mass unemployment, abuse of economic power), and laid the foundations for non-selective (functional) industrial policies to promote SMEs."

In the United States, the Small Business Administration sets small business criteria based on industry, ownership structure, revenue and number of employees (which in some circumstances may be as high as 1500 , although the cap is typically 500). Both the US and the EU generally use the same threshold of fewer than 10 employees for small offices (SOHO). In India a micro-enterprise is one where the investment in plant and machinery (their original cost excluding land, building and items specified by the Ministry of Small Scale Industries in its notification No. S.O. 1722(E) dated October 5, 2006) does not exceed Rs.25 lakh. A small enterprise is one where the investment in plant and machinery (see above) is more than Rs.25 lakh but does not exceed Rs. 5 crore. A medium enterprise is one where the investment in plant and machinery (see above) is more than Rs.5 crore but does not exceed Rs.10 crore. The definition of MSMEs in the service sector is: (1) Micro-enterprise: Investment in equipment does not exceed Rs.10 lakh. (2) Small enterprise: Investment in equipment is more than Rs.10 lakh but does not exceed Rs.2 crore. (3) Medium enterprise: Investment in equipment is more than Rs. 2 crore but does not exceed Rs. 5 crore. The Indian micro- and small-enterprises (MSEs) sector plays a pivotal role in the country's industrial economy. It is estimated that in value, the sector accounts for about 45 percent of manufacturing output and about 40 percent of total exports. In recent years, the MSE sector has consistently registered a higher growth rate than the overall industrial sector. The major advantage of the MSE sector is its employment potential at a low capital cost. According to available statistics (4th Census of MSME Sector), the sector employs an estimated 59.7 million people in 26.1 million enterprises; labor intensity in the MSE sector is estimated to be nearly four times that of large enterprises.

(3) Life-skills and Entreprenourships Capability Life skills are behaviors used appropriately and responsibly in the management of personal affairs. They are a set of human skills acquired via teaching or direct experience that are used to handle problems and questions commonly encountered in daily human life. The subject varies greatly depending on societal norms and community expectations. UNICEF states "there is no definitive list" of life skills but enumerates many "psychosocial and interpersonal skills generally 
considered important." It asserts life skills are a synthesis: "many skills are used simultaneously in practice. For example, decision-making often involves critical thinking ("what are my options?") and values clarification ("what is important to me?"). Ultimately, the interplay between the skills is what produces powerful behavioural outcomes, especially where this approach is supported by other strategies..." Life skills can vary from financial literacy, substance abuse prevention, [to therapeutic techniques to deal with disabilities, such as autism. Life skills curricula designed for K-12 often emphasizes communications and practical skills needed for successful independent living for developmental disabilities/special education students with an Individualized Education Program (IEP). However, some programs are for general populations, such as the Overcoming Obstacles program for middle schools and high schools. Parenting 2.0 (P2.0), LinkedIn's largest parenting group with more than 2,700 members (as of March, 2012),[8] defines Life Skills as all the non-academic foundational skills human beings learn and use to thrive individually and live optimally in community with others. P2.0's founder, Marlaine Paulsen Cover created a Life Skills Report Card that lists five basic skills categories: (1) Personal care. (2) Organization (3) Respect for self and others. Communication. (5) Social skills and proposes that life skills should be considered as important as academic skills.

Life skills are often taughtt in the domain of parenting, either indirectly through the orectly with the purpose of teaching a specific skill. Yet skills for dealing with pregnancy and parenting can be considered and taughtt as a set of life skills of themselves. Teaching these parenting life skills can also coincide with additional life skills development of the child. Many life skills programs are offered when traditional family structures and healthy relationships have broken down, whether due to parental lapses, divorce or due to issues with the children (such as substance abuse or other risky behavior). For example, the International Labor Organization is teaching life skills to ex-child laborers and risk children in
Indonesia to help them avoid the worst forms of child labor.

While certain life skills programs focus on teaching the prevention of certain behaviors the Search Institute has found those programs can be relatively ineffective. Based upon their research The Family and Youth Services Bureau, a division of the U.S. Department of Health and Human Services advocates the theory of Positive Youth Development as a replacement for the less effective prevention programs. Positive Youth Development, or PYD as it's come to be known as, focuses on the strengths of an individual as opposed to the older methods which tend to focus on the "potential" weaknesses that have yet to be shown. The Family and Youth Services Bureau has found that individuals who developed life skills in a positive, rather than preventive, manner feel a greater sense of competence, usefulness, power, and belonging. Beyond the K-12 domain, other life skills programs are focused on social welfare and social work programs, such as Casey Life Skills.This program covers diverse topics: career planning, communication, daily living, home life, housing and money management, self care, social relationships, work and study skills, work life, pregnancy and parenting

Entrepreneurship is the act and art of being an entrepreneur or one who undertakes innovations or introducing new things, finance and business acumen, in an effort to transform innovations into economic goods. This may result in new organizations or may be part of revitalizing mature organizations in response to a perceived opportunity. The most obvious form of entrepreneurship is that of starting new businesses (referred as startup company); however, in recent years, the term has been extended to include social and political forms of entrepreneurial activity. When entrepreneurship is describing activities within a firm or large organization it is referred to as intra-preneurship and may include corporate venturing, when large entities spin-off organizations.

According to Paul Reynolds, entrepreneurship scholar and creator of the Global Entrepreneurship Monitor, "by the time they reach their retirement years, half of all 
working men in the United States probably have a period of self-employment of one or more years; one in four may have engaged in selfemployment for six or more years. Participating in a new business creation is a common activity among U.S. workers over the course of their careers." And in recent years has been documented by scholars such as David Audretsch to be a major driver of economic growth in both the United States and Western Europe. "As well, entrepreneurship may be defined as the pursuit of opportunity without regard to resources currently controlled.

\section{Entrepreneurial activities}

are

substantially different depending on the type of organization and creativity involved. Entrepreneurship ranges in scale from solo projects (even involving the entrepreneur only part-time) to major undertakings creating many job opportunities. Many "high value" entrepreneurial ventures seek venture capital or angel funding (seed money) in order to raise capital to build the business. Angel investors generally seek annualized returns of $20-30 \%$ and more, as well as extensive involvement in the business.Many kinds of organizations now exist to support would-be entrepreneurs including specialized government agencies, business incubators, science parks, and some NGOs. In more recent times, the term entrepreneurship has been extended to include elements not related necessarily to business formation activity such as conceptualizations of entrepreneurship as a specific mindset (see also entrepreneurial mindset) resulting in entrepreneurial initiatives e.g. in the form of social entrepreneurship, political entrepreneurship, or knowledge entrepreneurship have emerged.

The entrepreneur is a factor in microeconomics, and the study of entrepreneurship reaches back to the work of Richard Cantillon and Adam Smith in the late 17 th and early 18th centuries, but was largely ignored theoretically until the late 19th and early 20th centuries and empirically until a profound resurgence in business and economics in the last 40 years. In the 20th century, the understanding of entrepreneurship owes much to the work of economist Joseph Schumpeter in the 1930s and other Austrian economists such as Carl Menger, Ludwig von Mises and Friedrich von Hayek.

Entrepreneurs have many of the same character traits as leaders, similar to the early great man theories of leadership; however traitbased theories of entrepreneurship are increasingly being called into question. Entrepreneurs are often contrasted with managers and administrators who are said to be more methodical and less prone to risk-taking. Such person-centric models of entrepreneurship have shown to be of questionable validity, not least as many real-life entrepreneurs operate in teams rather than as single individuals. Given entrepreneurship's potential to support economic growth, it is the policy goal of many governments to develop a culture of entrepreneurial thinking. This can be done in a number of ways: by integrating entrepreneurship into education systems, legislating to encourage risk-taking, and national campaigns. An example of the latter is the United Kingdom's Enterprise Week. Many of these initiatives have been brought together under the umbrella of Global Entrepreneurship Week, a worldwide celebration and promotion of youth entrepreneurship, which started in 2008.

(4) Self-fulfilment Attitude

Philosopher Alan Gewirth in his book Self-Fulfillment defined self-fulfillment as "carrying to fruition one's deepest desires or one's worthiest capacities." Another definition states that self-fulfillment is "the attainment of a satisfying and worthwhile life well lived." It is an ideal that can be traced to Ancient Greek philosophers, and one that has been common and popular in both Western and non-Western cultures.

Self-fulfillment is often seen as superior to other values and goals. Gewirth notes that "to seek for a good human life is to seek for selffulfillment". However, in modern philosophy, the ideal of self-fulfillment has become less popular, criticized by thinkers such as Hobbes and Freud, who feel there are conceptual and moral problems associated with it. It has been called an egoistic concept, impossible to achieve, with some suggesting that it is an obsolete concept that should be abandoned. Moral 
philosophers focus less on obtaining a good life, and more on interpersonal relations and duties owed to others. Similarly, whereas Plato and Aristotle saw the goal of the polis in providing a means of self-fulfillment to citizens, modern governments have given up on that, focusing rather on maintaining civic order. Despite the criticism, the concept of self-fulfillment still persists in modern philosophy, its usefulness defended by thinkers such as Gewirth himself.

Gewirth noted that the term selffulfillment has two near synonyms: selfrealization and self-actualization, used respectively by philosophers and humanist psychologists, whereas the term self-fulfillment is more commonly used outside those expert fields. Gewirth however argues that this concept is sufficiently different from those others to merit not being used as a synonym. Selfactualization in particular, often discussed in the context of Maslow's hierarchy of needs, is frequently defined as the "need for selffulfillment".

\section{METHODS}

This reserach based on descriptive quantitative reseach method. Population of this research were 542 pupils. But, only 226 students were joint as a respondent. The pupils who involved in this research were selected with randomized method (simple random sampling). The research location on Darul Ma'rifat Islamic Boarding School in Ponorogo, East Java. The observation, psychological scale and questionaire were used to colected the data. The Statistical Packgae for Social Science (SPSS) were used for analyzed the data. Regression (simple regression) was used to find the effect of life-skills and competency as an enterptrenorships towards self-fulfilment attitude of students at Darul Ma'rifat Islamic Boarding School in East Java.

\section{RESULT AND DISCUSSION}

Reserach Finding

There were two kinds of research finding in this research : (1) Descriptive analysis of respondent and spreading of mean data of variables. (2) The quanitiative analysis and testing of the hypotesis.

Table 1.1: The Descriptive Analysis of Respondent

\begin{tabular}{|c|c|c|c|}
\hline & The Categories & $\begin{array}{l}\text { Frequ } \\
\text { ency }\end{array}$ & $\begin{array}{c}\text { Percen } \\
\text { tage }\end{array}$ \\
\hline & Ages & & \\
\hline 1 & $18-19$ years old & 79 & 34,96 \\
\hline \multirow[t]{3}{*}{2} & $20-21$ years old & 147 & 65,04 \\
\hline & Sum & 226 & 100 \\
\hline & $\begin{array}{l}\text { The economic } \\
\text { background }\end{array}$ & & \\
\hline 1 & $\begin{array}{l}\text { High class level of } \\
\text { economic background } \\
\text { (family income }>\text { Rp } \\
10.000 .000 / \text { month) }\end{array}$ & 27 & 11,95 \\
\hline 2 & $\begin{array}{l}\text { Medium class level of } \\
\text { economic background } \\
\text { (family income Rp } \\
5000.000-\mathrm{Rp} \\
10.000 .000 / \text { month) }\end{array}$ & 168 & 74,34 \\
\hline \multirow[t]{3}{*}{3} & $\begin{array}{l}\text { Lower class level of } \\
\text { economic background } \\
\text { (family income < Rp } \\
5000.000 / \text { month) }\end{array}$ & 31 & 13,71 \\
\hline & Sum & 226 & $\mathbf{1 0 0 . 0 0}$ \\
\hline & The parents employee & & \\
\hline 1 & Civil servent & 87 & 38,50 \\
\hline 2 & Teachers / Lecturer & 62 & 27,43 \\
\hline 3 & $\begin{array}{l}\text { Enterprenour / private } \\
\text { sector }\end{array}$ & 56 & 24,78 \\
\hline \multirow[t]{3}{*}{4} & Public service & 21 & 9,29 \\
\hline & Sum & 226 & $\mathbf{1 0 0 . 0 0}$ \\
\hline & $\begin{array}{l}\text { The family social- } \\
\text { organization background }\end{array}$ & & \\
\hline 1 & Nahdlatul Ulama & 106 & 46,90 \\
\hline 2 & Muhammadiyah & 92 & 40,71 \\
\hline \multirow[t]{2}{*}{3} & Persis & 28 & 12,39 \\
\hline & Sum & 226 & 100 \\
\hline
\end{tabular}

Source s: The reserach reports 2012

According to Table 1.1 we found that most ages of the respondents at the Darul Ma'rifat Islamic Boarding School (Gontor 3) $20-21$ years old. This research found that most of the respondents were coming from medium class level of economic background. Beside that, 
the research also found that most of the parents employees were civil servent. After that, most of family social-organizational background was Nahdlatul Ulama.

Table 2.1 The mean spreading, frequency and percentage of life-skills and the enterprenorships capability

\begin{tabular}{l|c|c}
\hline $\begin{array}{c}\text { The } \\
\text { Categories }\end{array}$ & Frequency & Percentages \\
\hline High & 185 & 82,00 \\
\hline Low & 41 & 18,00 \\
\hline Sum & $\mathbf{2 2 6}$ & $\mathbf{1 0 0 . 0 0}$ \\
\hline
\end{tabular}

Sources : The research reports, 2012.

According to the Table 2.1 above, most of mean spreading were locating at the high level. It means that the life-skills and the entrepreneurships capability which implemented in Darul Ma'rifat Islamic Boarding School (Gontor 3) had internelized in their students bevahior, especially about their five spirits : Sincerity, simplicity, self-sufficiently, Islamic brotherhood, and freedom.

Table 3.1 The mean spreading, frequency and percentage of self-fulfilment

\begin{tabular}{l|c|c}
\hline $\begin{array}{l}\text { The } \\
\text { Categories }\end{array}$ & Frequency & Percentages \\
\hline High & 167 & 74,00 \\
\hline Low & 59 & 26,00 \\
\hline Sum & $\mathbf{2 2 6}$ & $\mathbf{1 0 0 . 0 0}$ \\
\hline
\end{tabular}

Sources : The research reports, 2012.

According to the Table 3.1 above, most of mean score spreading were locating at the high level. It means that most of the studnets at the Darul Ma'rifat Islamic Boarding School (Gontor 3) had a self-fulfilment; they wanted to involved with any kinds of bussines which held by the institution, like ; agriculture, plantations, forestry, trade and services.
Table 4.1-4.2 The Correlation Analysis

\begin{tabular}{|ll|l|l|}
\hline & Life-skill & $\begin{array}{c}\text { Self- } \\
\text { fulfilment }\end{array}$ \\
\hline $\begin{array}{ll}\text { Life- } \\
\text { skills }\end{array}$ & Pearson Correlation & 1 & $.847(* *)$ \\
& Sig. (2-tailed) & & .000 \\
Self- & Pearson Correlation & 226 & 226 \\
fulfil & Sig. (2-tailed) & $.047(* *)$ & 1 \\
ment & $\mathrm{N}$ & 226 & 226 \\
\hline \multirow{2}{*}{$* *$ Correlation is significant at the 0.01}
\end{tabular}
level (2-tailed).

\begin{tabular}{|ll|l|l|}
\hline & $\begin{array}{c}\text { Entrepen } \\
\text { eurships } \\
\text { capability }\end{array}$ & $\begin{array}{c}\text { Self- } \\
\text { fulfilment }\end{array}$ \\
\hline $\begin{array}{l}\text { Entrepen } \\
\text { eurships } \\
\text { capability }\end{array}$ & $\begin{array}{l}\text { Pearson } \\
\text { Correlation }\end{array}$ & 1 & $.763(* *)$ \\
& Sig. (2-tailed) & & .000 \\
Self- & Pearson & 226 & 226 \\
fulfilment & Correlation & $.763(* *)$ & 1 \\
& Sig. (2-tailed) & .000 & \\
& N & 226 & 226 \\
\hline
\end{tabular}

** Correlation is significant at the 0.01 level (2-tailed).

According to The table 4.1-4.2 above, we got information that $r$ score $=0.847$. Then the table ${ }_{\text {score }}=1,64$ and $p=0.000<0.05$. It means $\mathrm{H}_{\mathrm{o}}$ was rejected and recieved $\mathrm{H}_{1}$. So, there were any correlation between life-skills and selffulfilment. we also got information that $\mathrm{r}_{\text {score }}=$ 0.763 . Then the table score $=1,64$ and $p=0.000<$ 0.05 . It means $\mathrm{H}_{\mathrm{o}}$ was rejected and recieved $\mathrm{H}_{1}$. So, there were any correlation between entrepeneurships capability and self-fulfilment.

Table 5.1 An Effect of Life-Skills and Entreprenuurships Capability Towards Selffulfilment

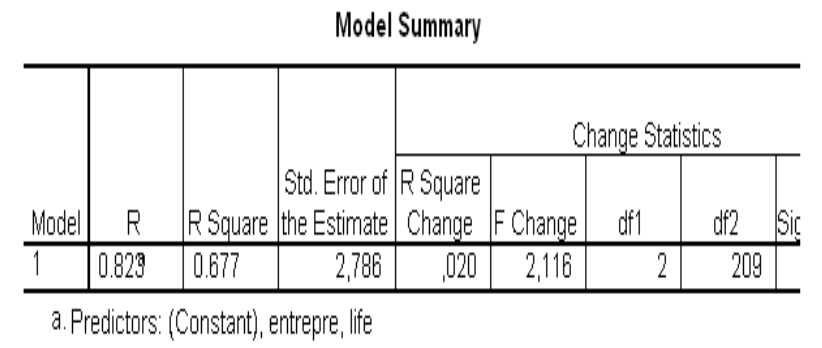

According to The table 5.1 above, we got information that $\mathrm{R}_{\text {score }}=0.823$ and $\mathrm{R}_{\text {square }}=$ 
0.677. It means that an effect of Life-skills and Entrepreneurships Capability towards selffulfilment of students at the Darul Ma'rifat Modern Islamic Boarding School was $67,7 \%$. Then $32,3 \%$ caused another effect, like : motivation, interest and social support etc.

Table 6.1 The Units of Economy which held By Gontor Modern Islamic Boarding School

\begin{tabular}{|c|c|c|}
\hline No. & Units of Economy & Founded \\
\hline 1. & Rice Mills & 1970 \\
\hline 2. & Darussalam Press & 1983 \\
\hline 3. & KUK Grocery & 1985 \\
\hline 4. & KUK Building Materials & 1988 \\
\hline 5. & La Tansa Book Store & 1989 \\
\hline 6. & UKK Mini Market & 1990 \\
\hline 7. & La Tansa Meat Ball & 1990 \\
\hline 8. & KUK Photostates & 1990 \\
\hline 9. & Gambia Telecomunication & 1991 \\
\hline 10. & La Tansa Pharmacy & 1991 \\
\hline 11. & Ice Mills & 1996 \\
\hline 12. & Daily Needs Supplier & 1997 \\
\hline 13. & Transportation & 1998 \\
\hline 14. & Al-Azhar Canteen & 1999 \\
\hline 15. & Darussalam Inn & 1999 \\
\hline 16. & Sudan Telecomunication & 1999 \\
\hline 17. & $\begin{array}{l}\text { Darussalam Computer } \\
\text { Centre }\end{array}$ & 1999 \\
\hline 18. & Asia Photostates & 2000 \\
\hline 19. & $\begin{array}{l}\text { East-La Tansa Distributor } \\
\text { Centre }\end{array}$ & 2002 \\
\hline 20. & Slaughtering of Chicken & 2002 \\
\hline 21. & $\begin{array}{l}\text { Mantingan La Tansa } \\
\text { Distribution Centre }\end{array}$ & 2003 \\
\hline 22. & La Tansa Bakery & 2003 \\
\hline 23. & $\begin{array}{lll}\text { La Tansa } & \text { Mineral } \\
\text { Drinking Water } & \\
\end{array}$ & 2004 \\
\hline 24. & Sport Store & 2005 \\
\hline 25. & Convection & 2006 \\
\hline 26. & $\begin{array}{l}\text { Al-Azhar } \\
\text { Telecomunication }\end{array}$ & 2006 \\
\hline 27. & Chicken Noodle & 2006 \\
\hline 28 & La Tansa Tea & 2009 \\
\hline 29. & La Tansa BMT & 2010 \\
\hline 30. & Siman BMT & 2010 \\
\hline 31. & Ice Cream & 2012 \\
\hline
\end{tabular}

Sources : The research reports, 2012
According to The table 6.1 above, we got an information that Gontor as Islamic Boarding School had been handling many kinds of small and medium industry for supporting their institution and building one of their five spirits (Darussalam Gontor); self-sufficiency. For example; the innovation of La Tansa Ice Cream which founded 2012 got a good response from the santri (students) and another consummers increases more and more, La Tansa Book Store and Sport Shop had some relationships with the community. Moreover, this activity was a real step of this economy units to compete with other book-store and other sport shop, La Tansa Mini Market (Mart), La Tansa Bakery and La Tansa Transport were built not only to serve the students but also their parents and local community. The cooperation operated officially under decree of the Department of Cooperation of the Republic of Indonesia Number: 837/BH/II/1996 date on July 1996.

\section{DISCUSSION}

This research found that: (1) Most of mean spreading were locating at the high level. It means that the life-skills and the entrepeneurships which implemented in Darul Ma'rifat Islamic Boarding School (Gontor 3) had internelized in their students bevahior, especially about their five spirits : Sincerity, simplicity, self-sufficiently, Islamic brotherhood, and freedom. (2) Most of mean score spreading were locating at the high level. It means that most of the studnets at the Darul Ma'rifat Islamic Boarding School (Gontor 3) had a selffulfilment; they wanted to involved with any kinds of bussines which held by the institution, like ; agriculture, plantations, forestry, trade and services. (3) The $r_{\text {score }}=0.847$. Then the table score $=1,64$ and $p=0.000<0.05$. It means $\mathrm{H}_{\mathrm{o}}$ was rejected and recieved $\mathrm{H}_{1}$. So, there were any correlation between life-skills and self-fulfilment. we also got information that $r$ score $=0.763$. Then the table ${ }_{\text {score }}=1,64$ and $p=0.000<0.05$. It means $\mathrm{H}_{\mathrm{o}}$ was rejected and recieved $\mathrm{H}_{1}$. So, there were any correlation between entrepeneurships capability and self-fulfilment. 
This research supported another research by Emnis Anwar that found: (1) Self-sufficiency as a soul and spirits of Gontor Modern Islamic Boarding School. (2) Institutional sufficiency includes; (a) educational aspect, (b) financial aspect, (c) political aspect, (3) Individual sufficiency of students, includes; (a) intellectual, (b) bahavioral, (4) Self-sufficiency implemented with balancing knowledge between cognitive, affective and psycomotoric, mental-attitude, mental-spiritual, social, morale and life-skills. (5) The educational of self-sufficiency taught with practicing, conditioning, guidance and instruction. The self-sufficiency was implemented not only in the class room (teaching and learning process) but also as hidden curriculum (extra and co-curriculum) and life-style at the boarding school. The supporting factors of implementing selfsufficiency education in Gontor was caused the establishment of educational system, integrated school and madrasa, inovlving of steakholders, consistancy rule of law and the main important things that Gontor was establish with in waqf of ummah. Entrepreneurship can play an important role in structural economic change and in improving wellbeing. Governments and international institutions are investing increasing resources to promote entrepreneurship.

According to a search of Global Entrepreneurship Monitor in 2011 Brazil had 27 million adults aged between 18 and 64 either starting or owning a business. It means that more than one in four brazilian adults were entrepreneurs. In comparison to other 54 countries studied, Brazil stood out as the thirdhighest one in absolute number. Another interesting fact found by Ipea, a government agency, is that 37 million jobs in Brazil were associated to business with up to 10 employees. The most recent research of Global Entrepreneurship Monitor revealed this year (2012) that $50.4 \%$ of the Brazilian initial entrepreneurs are men, $33.8 \%$ are in the $35-44$ age group, $36.9 \%$ did highschool and $47.9 \%$ earn 3-6 Brazilian minimum wages. These are the highest percentage of data that contradict with the data lower, $49.6 \%$ of initial entrepreneurs Brazilian female, only $7 \%$ of 55
64 years, $1 \%$ with postgraduate incomplete and $1.7 \%$ entrepreneurs who earn more than 9 times the minimum wage in Brazil. Based on the research above we knew that the age was not barrier to the people tobe an entreprenuerships. So that, all the students at Darul Ma'rifat Modern Islamic Boarding School also can be a potential entrepreneurship, because they had a life-skills and entrepreneurship experiences in their institution.

\section{CONCLUSION}

Life-skills and the entreprenuurship capability were implemented during the students studied (teaching-learning process) at Darul Ma'rifat Modern Islamic Boarding School. Lifeskills and entrepreneurship capability had taught by the teacher and Kiyai through learning by duing with joint all kinds of buissiness (small and medium industry) which handle by Gontor. The students could develop their knowledge about their potencial capability. So, they knew what they will do for the future. Then, they had an interest to build their own company, like: Dede Suleman as a former students of Gontor Modern Islamic Boarding School who had a bussines in Japanese restaurant "My Bento". All kinds experiences in life-skill and entrepreneurships capability built the sense of confident at Darul Ma'rifat Modern Islamic Boarding School students.

The small and medium industry as a tools for learning by doing to the Darul Ma'rifat Islamic Boarding School students. They knew how to manage the business and making a Business plan, how to market their product, how to handle their competitor, how to learn about consumers behavior, how to advertise their product, how to manage the human resources, how to produce the product, how to make balance the reports etc. So that, all kinds of knowledge that (during they were studying in Darul Ma'rifat Modern Islamic Boarding School) they had could increase their self-fulfilment. On the other hand, self-fulfilment can be improved by life-skills and entrepreneurships capability.

Beside that, all kinds of small and medium industry which handle by Gontor relatively could be coverd all they needs for 
sustaining their institutions, like ; (1) Develop a new building i.e. class-room, mosque, dormitory etc all over Gontor (as we knew that Gontoer had a few branch, starting from Gontor II Gontor XIII which exist at all around province in Indonesia) and include of Darussalam Institute of Islamic Studies (ISID), (2) Develop their human resorces with sending the teachers and lecturers continue their study to overseas, joint to the international seminars or workshops. (3) Building a new Business product or investment. (4) Protecting their own values. Their mottoes ; Noble character, Sound body, Broad Knowkedge, Independent mind and their five spirits; Sincerity, Simplicity, Self-sufficiency, Islamic brotherhood, Freedom. (*)

\section{REFFERENCES}

Abaza, Mona, 1994. Islamic Education, Perceptions and Exchanges: Indonesian Students in Cairo, Paris: Cahier de Archipel

Abdullah, Taufik, 1987. Islam dan Masyarakat: Pantulan Sejarah Indonesia, Jakarta: LP3ES

Azra, Azyumardi, 1992. "The Transmission of Islamic Reformism to Indonesia: Network of Middle-eastern and MalayIndonesian "Ulama" in the Seventeenth and Eighteenth", Ph.D dissertation, Colombia University, New York.

Bidang Tarbiyah PP Persis. 1996. Pedoman Sistem Pendidikan Persatuan Islam. Bandung: PP Persatuan Islam, 1996

Boland, Bernard Johan. 1982. The Struggle of Islam in Indonesia 1945-1947. Leiden: E.J. Brill

Dhofier, Zamakhsari, 1995. Tradition \& Change In Indonesian Islamic Education, Jakarta: MORA, 1995

Dhofier, Zamakhsyari. 1984. Tradisi Pesantren: Studi tentang Pandangan Hidup Kyai. Jakarta: LP3ES

Direktori Pondok Pesantren, 2000. Proyek Peningkatan Pondok Pesantren, Direktorat Pembinaan Perguruan Agama Islam Direktorat Jenderal Pembinaan Kelembagaan Agama Islam Departemen Agama
Effendy, Bahtiar, 1994. Islam and the State: The Transformation of Islamic Political Ideas and Practices in Indonesia, (Michigan: UMI Dissertation Services

Encyclopaedia Britannica Deluxe Edition CDROM.

Ensiklopedi Islam di Indonesia, Departemen Agama, 1992/1993.

Federspiel, Howard M. 1970. Persatuan Islam: Islamic Reform in Twentieth Century Indonesia. New York: Cornell University

Feisal, Yusuf Amir. 1993. "Pesantren Gaya Baru, Sebuah Usulan." Risalah, No. 7/ Nopember h. 16-17.

Geertz, Clifford, 1960. "The Javanese Kijaji: the Changing Role of a Cultural Broker”, CSSH, vol. 2, pp. 228-249.

Geertz, Clifford, 1960. The Religion of Java, New York: The Free Press.

Hamid, Abu, 1983. "Sistem Pendidikan Madrasah dan Pesantren Di Sulawesi Selatan", dalam Taufik Abdullah (ed), Agama dan Perubahan Sosial, Jakarta: Rajawali Press, cet. I, h. 385-389.

Hamid, Hamdani. 1993. Usaha Pembaharuan Pendidikan: Perubahan Kurikulum Pesantren Persatuan Islam. Bandung: CV. Dasita

Hamzah, Abu Bakar, 1981. Al-Imam: Its Role in Malay Society 1906-1908, Kuala Lumpur: Pustaka Antara

Horikoshi, Hiroko, 1987. Kiyai dan Perubahan Sosial, Jakarta: P3M

Hurgronje, C. Snouck, 1931. Mekka in the Latter Part of the 19th Century, Leiden: E.J. Brill

Jabir, Husain ibn Muhsin ibn Ali, 1984. AlThariq ila Jama'ah al-Muslimin, Kuwait: Dar al-Dakwah

Johns, A.H., 1980. From Coastal Settlements to Sekolah Islam and City: Islamization in Sumatra, the Malay Penensula and Java", dalam, Indonesia: The Making of A Culture, Canbera: Research School for Pacific Studies

Karim, M. Rusli, 1985. Dinamika Islam di Indonesia: Suatu Tinjauan Sosial dan Politik, Yogyakarta: Hanindita 
Kartodirdjo, Sartono, 1966. The Peasant Revolt of Banten in 1888: Its Conditions, Courses, and Sequel, The Hague: Martinus Nijhoff

Laporan Akhir, 2003. Studi Pengembangan Sub-Sektor Pendidikan Madrasah pada Proyek Peningkatan Perguruan Agama Islam Tingkat Menengah ADB Loan 1519-INO, Jakarta: PT Amythas Experts and Associates

Matheson, Virginia dan M.B. Hooker,1988. "Jawi Literature in Patani: the Maintenance of an Islamic Tradition", JMBRAS, vol. 16, hal. 1-86.

Noer, Deliar, 1980. Gerakan Modern Islam di Indonesia 1900-1942, Jakarta: LP3ES

Othman, Mohammad R, 1994."The Middle Eastern Influence on the Development of Religious and Political Thought in Malay Society, 1880-1940”, Dissertasi Ph.D., Uni-ver-sity of Edinburgh

Rahman, Ahmad, 1996. Guruta H. Muhammad As'ad Al-Buqisiy (Pelopor Pendidikan di Sulawesi Selatan), Seminar Hasil Penelitian Rutin (tidak diterbitkan), Badan Litbang Agama, Balai Penelitian Lektur Keagamaan Ujung Pandang

Risalah, 1993. "Menuju Pesantren Mumpuni." No. 7/Nopember, h. 14-15).

Ristiyanto, Sugeng, 2000. A Study on Management Perspective in Relation to the Existance of Islamic Institution: Pesantren Islam AI-Mukmin Ngruki Sukoharjo, Thesis pada Program magister Islamic Studies di Universitas Muhammadiyah Surakarta.

Rosidi, Ajip. M. Natsir: 1990. Sebuah Biografi. Jakarta: Giri Mukti Pusaka

Setiawan, Aking. 1985. "Mencari Rumusan Tujuan Pendidikan Pesantren" Risalah, No.3, Th.XXIII Sya'ban-Ramadhan $1405 \mathrm{H} / \mathrm{Mei}$

Statistik Madrasah Indonesia 2002-2003, Depag.
Statistik Pondok Pesantren Indonesia 2002-2003, Depag

Steenbrink, Karel A., 1986. Pesantren, Madrasah dan Sekolah: Pendidikan Islam dalam Kurun Modern, Jakarta: LP3ES

Turmudi, Endang, 1995, "The Charismatic Leadership of The Kyai in Contemporary East Java: Field Notes from Jombang”, dalam Masyarakat Indonesia: Majalah Ilmu-Ilmu Sosial Indonesia, year XXII nomor 2, Jakarta: LIPI.

Umam, Saiful dan Azyumardi Azra, 1998. Tokoh dan Pemimpin Agama: Biografi Sosial-Intelektual. Jakarta: Badan Litbang Agama, Departemen Agama

UU No. 20, 2003 tentang Sistem Pendidikan Nasional (Sisdiknas)

UU No.4, 1950; UU No. 12 year 1954

Wahid, Abdurrahman, 1974. "Pesantren sebagai Subkultur", dalam M. Dawam Rahardjo, (ed.), Pesantren dan Pembaharuan, Jakarta: LP3ES

Wijoyo, Alex Soesilo, 1997. "Shaykh Nawawi of Banten: Texts, Authority, and the Gloss Tradition", Ph. D. Dissertation, Colomnia University, New York.

Wildan, Dadan, 1997. Yang Da'i Yang Politikus: Hayat dan Perjuangan Lima Tokoh Persis. Bandung: PT. Remaja Rosda Karya

Yatim, Badri, 1999. Sejarah Sosial Keagamaan tanah Suci: Hijaz (Mekah dan Madinah) 1800-1925, Jakarta: Logos 